\title{
If Not Now, Then When? The Significance of CISG Ratification for Indonesia
}

\author{
Ratu Wulandari ${ }^{1}$ \\ ${ }^{1}$ Erasmus University of Rotterdam, Netherlands \\ wulandariratu@hotmail.com
}

\begin{abstract}
Introduction to The Problem: In this 21st century, Indonesia has not ratified the United Nations on Contract for the International Sales of Goods (CISG). Indonesia's government put several reasons for not becoming part of this critical convention, and the government did not see the ratification as urgent matters. However, these excuses did not find relevant anymore because more and more countries worldwide ratified the CISG, including North Korea.
\end{abstract}

Purpose/Objective Study: The objective of this article is addressing the issue of Indonesia has not yet ratify the United Nations on Contract for the International Sales of Goods (CISG) despite the rise of export and import activities conducted by Indonesian enterprises.

Design/Methodology/Approach: The methodology used in this article is based on the literature review of CISG, Indonesian development of CISG, and minor comparative analysis between the signatory and non-signatory countries.

Findings: The ratification of CISG would provide more benefits and outweighed its disadvantages because CISG presents legal certainty to international contract law since the Indonesian Civil Code failed to address this issue. CISG ratification will also strengthen the Indonesian legal system, legal institutions, and legal practitioners.

Paper Type: Research Article

Keywords: CISG; Indonesian Ratification; International Contract; International Business

\section{Introduction}

The United Nations Convention on Contracts for the International Sales of Goods (CISG) is a remarkable international transaction treaty (Coyle, 2016). It is a uniform international sale of contract that the United Nations Commission has drafted on International Trade Law (UNCITRAL). At the current state, 94 countries have ratified this convention. CISG has primarily designed to meet international commerce's needs, increasing certainty among commercial transactions and lowering their expenses (UNCITRAL, 2020). The most astonishing feature of CISG is the party autonomy principle; parties can choose to opt-in or opt-out the application of CISG (De Ly, 2005). CISG members are increasing every year (Checkley, 2020; Ferrante, 2019), which is in-line with the volume of international trade transactions. According to the World Trade Organization report (WTO) on World Trade Statistical Review in 2019, the volume of worldwide merchandise transactions increased by 10 percent in 2018, with 
Asia as the primary contributor to global imports' growth. This increment brings GDP growth along the way. Both have increased by 26 percent since 2008 (Economic Research and Statistics Division \& The International Trade Statistics Section, 2019).

Within Asia, Indonesia plays an essential role in international trade. The country is the fourth-largest population in the world (Maulana, Obst, \& Khawaja, 2018; Ngoc, 2016), with more than 273 million inhabitants (Worldometer, 2021). According to WTO data in 2019, on average, Indonesia contributes to the top 30 export and import activities in the area of world merchandise trade, commercial services, and top 10 for agricultural products (UNCITRAL, 2020). It means Indonesian business practices connect closely with the international contract. However, the county has not ratified the CISG (Haeruddin, Mansur, Mansur, Thaief, \& Haeruddin, 2020). Indonesia's very basic contact is regulated under Burgerlijk Wetboek voor Indonesie (KUHPerdata) or civil code of Indonesia, which initially came from the Dutch colonialization era. This civil code has become the fundamental source in every agreement made with the Indonesian party for national and international contracts (Adiyanto, 2019).

This civil code has been enacted in Indonesian law since 1848, and no significant change had ever been made. The only follow-up for Indonesian law in the international agreement is stated under Law No. 24, the Year 2000 that concerns about International Agreement. This agreement only covers the international law that is written and made for the public interest. There is no specific law made for international private law; subsequently, this led to uncertainty for international contract law. There are no different rules in regulating domestic and international sales contracts (Oktaviandra, 2018). A dispute arises between Indonesia and CISG member states, and no choice of law is being made. The judiciary procedures in CISG country will use CISG as the law that governs the contract (Case 54: CISG 1(1)(a);1(1)(b);4;79 Italy: Tribunale Civile di Monza between Nuova Fucinati S.p.A. v. Fondmetal International A.B., 1993). This will create less bargaining position for the Indonesian party, especially if the lawyers lack CISG knowledge.

Therefore, this article will try to examine Indonesia's position in international trade law, primarily on the urgency of the Indonesian government need to ratify the CISG to give legal certainty for the cross-border transaction, the business community, legal practitioners, and institution because the benefit of CISG is overweighted its drawbacks. This article comprises the history of CISG, what contain in CISG, and its advantages, especially concerning party autonomy. Indonesian standpoints on CISG and the Indonesian government's recommendation to consider this treaty are essential for future international transactions in Indonesia. The methodology used in this article is based on the literature review of CISG, Indonesian development of CISG, and minor comparative analysis between the signatory and non-signatory countries.

\section{Methodology}




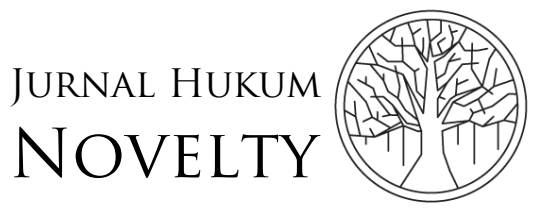

Volume 12, Issue 01, 2021, pp. 124-136

P-ISSN: $1412-6834$

E-ISSN: 2550-0090

The methodology used in this article is based on the literature review of CISG, Indonesian development of CISG, and minor comparative analysis between the signatory and non-signatory countries.

\section{Results and Discussion}

\section{A Brief History of CISG}

CISG has renowned for a bridge between vertical and horizontal approach; combining party autonomy and commercial practice, unification law between civil and common law countries, and an escape plan from sophisticated legal notions so every trade practitioner can embed easily, and it can be easily accessible for international trades all over the world. It is an undisputed fact that more and more countries now ratified the convention (UNCITRAL, 2015).

CISG has a long-standing history. Before it was formed, the domestic sale law became the only source of law for international trade. Domestic sales law has exhausted to cover international disputes relating to the cross-border transaction because of the international transaction's international nature. In 1920, the International Institute for the Unification of Private Law (UNIDROIT) codified Uniform Law on the International Sale of Goods (ULIS) and the Uniform Law on the Formation of Contracts for the International Sale of Goods (ULFIS) in 1964. The ultimate achievement of these two laws was cutting the cost and reduce the disadvantages of forum shopping among international merchants (Forum shopping defines as a practice of choosing the court of jurisdiction that has the most favorable rules or laws for the position being advocated) (Ewert \& Weslow, 2011). However, these laws are exceptionally radical toward domestic sales law and only applied in European continental, which was no longer relevant due to international commerce activity expansion. They have also failed in obtaining trust from the international community and were criticized for giving a solid impression to prefer law and practice, which rendered the western, developed world grounded in civil law traditions (Srivastava, 2020). Since not all the cross-border transaction issues can be settled within these systems, they finally resembled an alternative solution.

In 1977, the United Nations Commission on International Trade Law (UNCITRAL) working group on sales undertook efforts to work on the paper until CISG finished in September. Twenty-one countries have signed and indicated their intention to the ratification, and the sixty-two states had been adopted CISG to their national legislation (Farnsworth, 1984). Many states have adopted the CISG not long after it was launched, indicated CISG as the basis for a modern lex mercatoria, (Matera, 2004), which provides legal certainty for international private law.

The CISG is also famous for its non-monopolistic view. Instead of creating an absolute power that outlaws certain transactions or invalidating the proscribed contract and preempts domestic law, the CISG respects the parties' contractual arrangement. The parties have the entire decision of including (opt-in) or excluding (opt-out) CISG in 
whole or part of their agreements, resulting in their contract overcoming any conflicting uniform law provision (De Ly, 2005). It answers issues in the contract that parties had failed to address, such as breach of contract, and it compromises domestic sales rules such as the United States' Uniform Commercial Code (De Ly, 2005).

From the establishment of CISG until its current state, 94 members state has adopted this convention. Portugal is the newest member (it will enter into force on 1 October 2021) (UNCITRAL, 2020), making CISG applied to all EU member states the UK after Brexit. The adoption of CISG comes from different legal systems in the world. Though, there should be noted that in practice, some lawyers in CISG member states sometimes choose not to include CISG in their contracts. For instance, in the United States, between $55-71 \%$ of lawyers chose to opt-out. In Germany, around $45 \%$ of lawyers prominently opt-out when advising their clients, and 55\% of Australian lawyers did the same. On the contrary, CISG shows its trend in the Chinese lawyers due to the Chinese economy's bargaining strength in global trade and difficulties in access to Chinese law; it such a powerful force within the choice of law (Spagnolo, 2009a).

\section{Scheme of CISG and Its Application}

In a nutshell, CISG consists of four sessions (UNCITRAL, 2015):

1. The first part from chapter II and II (article 1-13) concern with the sphere of application and general provisions,

2. The second part (articles 14-24) deals with the rules of contract formation,

3. The third part is known as the most significant part of the convention titled "sales of goods" (articles 25-29), deals with general provisions of sales of goods, (article 30-44) obligation of the seller, (article 45-52) remedies for breach of obligation, (article 54-60) obligation of the buyer, (article 61-65) remedies for breach of contract by the buyer, (article 66-70) passing of risks.

4. The fourth part contains provision commonly apply to the seller and buyer related to anticipatory breach (article 71-72), installment sale (article 73), measures of damages (articles 74-77), mitigation of damage (article 77), and entitlement to interest (article 78)

5. The last part deals with final provisions such as implementation, ratification, accession, and reservation to the convention.

The rules under CISG are generally characterized as substantive law instead of procedural law. When a court decides the merit of a sales agreement case, the judge must refer to this law. In order to implement the substantive law to the merit of the case, the first thing first is to decide whether CISG applies. The sphere of application is stated in article one of CISG. This convention applies to the parties if "(a) when the states are contracting states or (b) when the rules of private international law led to the application of the law of a contracting state." ( ${ }^{1} \mathrm{CISG}$, article 1(a)(b)). The scope of application also renowned for automatic and conditional application; the automatic 
application applies if a dispute arises between contracting parties that resided in CISG member states.

Under Buyer SA v. Seller Co. Ltd, before the International Chamber of Commerce (ICC), the case is between Romania and a seller from China. Both parties agreed to enter into a sale and purchase agreement. The issue started when the buyer failed to open a letter of credit in time that led to a request for arbitration in ICC. The contract is subject to Romanian law, and there was no expressed agreement of excluding CISG. The sole arbitrator then concluded that CISG applied as the substantive law for the dispute because both parties are contracting states in CISG and the law subject to Romanian law, as the CISG member (In the case of Buyer S.A. v. Seller Co. Ltd (Final Award), ICC Case No.18643) (Schill, 2020).

It is relatively easy to determine the automatic application, and the tricky part is related to the conditional application. This application commonly occurs if one of the parties is not a member state of CISG. For instance, a dispute between the Indonesian buyer v. Singaporean seller happens on a sale and purchase agreement, and there is no law choice in the contract. However, the disputed forum is subject to Singapore International Arbitration Center (SIAC). The arbitrator in SIAC first examines the case's substantive law since Singapore is a party to CISG, whereas Indonesia is not. Hence, the CISG application scope falls under article 1(b), the rules of private international will apply, which also called the conflict of laws, a difference between the laws of two or more jurisdictions with some connection to a case, such that the outcome depends on which jurisdiction's law will be used to resolve each issue in dispute. Suppose both the contracting parties reside in European Union. In that case, once a conflict of law arises, the judge or arbitrator will refer to the convention on the Law Applicable to Contractual Obligation 1980 (Rome Convention), and it will subject to the law of the seller's location.

Furthermore, several countries are reserved for opting out of article 1(1)(b) as stipulated in article 95 declarations. These countries are Slovakia, Singapore, China, and the United States. A court in non-CISG states determines law conflicts using traditional choice-of-law rules, for example, lex fori and lex causae approaches. Depending on the conditions, those rules could lead to the application of the CISG or not. The same consideration applies in International commercial arbitration (Lookofsky, 2017).

In addition to CISG's scope of application, one of the CISG advantages, this convention can also apply if the parties are located in different countries (which need not be contracting states). International private rules lead to applying the law of a contracting state (CISG art. 1(1)(b)). Taking back the example between Indonesian seller and Singaporean buyer, if the international sales contract is subject to Singaporean law, CISG will automatically apply because Singapore is a member of CISG. 
The CISG rule only limits the international contract of sale of goods. The convention stated that CISG "does not apply to the contract in which the respondent part of the obligations of the party who furnishes the goods consists in the supply of labor or other services." Hence, if the sales and goods' agreement contain labor or skill, such agreement is exempted from CISG application. Formation of contract in CISG has specifically regulated under article 4 and part II formation of the contract. Generally, contract formation starts from negotiation, offer, letter of intent, and acceptance. Under English law, the negotiations mean inquiries and invitation to contract, including the quotation or tender from potential parties. The offer means a statement deliberated to result in a binding contract if entirely accepted by the offeree. The acceptance has to be unconditional and unqualified, results in the act of acceptance through action. The acceptance form is varied, such as a slip confirmation, countersigned acceptance form by signed or acknowledged (Murray, 2012).

Under Indonesian Civil Code (KUHPerdata), the contract formation is stipulated in the book three and four starting from article 1342 to 1351 . Article 1320 states that the validity of contract consists of four elements:

1. Subjective matters, such as the ability of the party to agree;

2. Agreement between the parties;

3. The existence of an object;

4. Lawful cause or the object is not against the applicable law, morality, and public order.

Furthermore, KUHPerdata also addresses fundamental principle in the contract, inter alia:

1. Freedom of contract or party autonomy gives parties full power to form an agreement, which binds them (Art. 1338 KUHPerdata).

2. Concensualism, the agreement might come into force if both parties are mutually consenting (Art. 1320 (1) KUHPerdata);

3. Pacta sunt servanda, the binding effect of the agreement to the parties (Art. 1338 (1) KUHPerdata);

4. Good faith principle, an agreement has to be made based on good intention (Art. 1338 (3) KUHPerdata);

5. Decency principle, the agreement has to be made based on virtue and ethics (Art. 1339 KUHPerdata);

6. Personality principle, the agreement cannot be made by one party itself (Art. 1340 KUHPerdata).

The CISG formation of contract comprises the basic principle of contract similar to KUHPerdata. Offer and acceptance build fundamental elements in the contract formation process along with the nature of an offer (Art. 14 CISG). Offer is effective when it reaches the offeree (Art. 15(1) CISG), withdrawal of offer before the receipt (Art. 15 (2) CISG), revocation of offer before acceptance (CISG art.16), and termination by rejection (CISG art. 17). Offer necessitates the offeror's intention to be 
bound to the contract; the element of intention is specifically defined in the separate articles under the convention. A proposal describes in article 14(1) as 'sufficiently definite' if it indicates the goods within implicit or explicit fixes price (CISG art. 14(a)(b)). For example, purchasing a 300-euro PlayStation five through e-commerce would satisfy this element. A big question usually arises in forming a contract whether the international sales contract must be in writing. To answer this question, CISG position informal requirement for international contract stated under article 11, 'A contract of sale need not be concluded in or evidenced by writing and is not subject to any other requirement as to form,' (CISG Art. 11) it provides complete freedom as to form, 'contract in writing can only be modified or terminated in writing if it so provides.' (CISG Art.29) Further, the contract is included in the form of telegram and telex (CISG art. 13).

Acceptance under CISG starts when "...the moment the telegram is handed in for dispatch or from the date shown on the letter or, if not such date is shown, from the date shown on the envelope. A period of time for acceptance fixed by the offeror by telephone, telex, or other means of instantaneous communication..." (CISG art. 20(1)). A form of acceptance becomes effective communication has been made, either verbally, by telephone, or by telex; a mere silence is not sufficient for a form of acceptance (CISG art. 18(1)). Despite the explicit communication, acceptance by performance, when an offeror request performance in return for his/her promise and the offeree fulfills the act, this full performance constitutes sufficient a form of acceptance (CISG art. 18(3)). Even if CISG was formed in the 1980s, the application of CISG extends to electronic contracts or e-commerce, which is relevant to today's practice. An electronic contract is not fundamentally different from a conventional paper-based contract. CISG courts, arbitrators, and CISG-Advisory Council shared their opinion that the convention can serve electronic communication and traditional communication (Lookofsky, 2017). (Advisory Council is founded by the Pace Institute of International Commercial Law and the Center for Commercial Law Studied at Queen Mary College. The focus of AC is issuing opinion regarding the interpretation and application of CISG (Alper, 2021).

CISG accommodates freedom of contract by means of parties can choose to opt-in or opt-out the application of this convention (CISG art. 6). As international commercial sales are generally regulated by party autonomy, the CISG bestows basic default rules on the contract, such as the general condition of sale contracts and contract formation (De Ly, 2005). If the contracting party chose to opt-out CISG application, they could expressively exclude the CISG application in their contract. According to Lisa Spagnolo, she researched rationality, irrationality, economics, and psychology reasons for legal practitioners to opt-in and out of the CISG. She found out that most lawyers chose to disregard the CISG application in their client's contract. Surprisingly, $54 \%$ of US lawyers responded that they disregarded the CISG application is not widely known. This case draws a similar situation in $52 \%$ of German lawyers. Based on not knowing or more excellent baseline, unfamiliarity is mainly derived from education. 
The lawyers have less exposure to CISG because the University teaching does not include CISG learning in their curriculum (Spagnolo, 2009a).

The other reason for unfamiliarity with the CISG is work experience; this happens when lawyers barely litigate any case related to the CISG. The jurisdiction that produces a high amount of CISG disputes is bound to have more lawyers familiar with the CISG (Spagnolo, 2009a). Regarding the unfamiliarity of lawyers to opt-out, CISG is in question because when clients seek legal advice for contractual terms and unfamiliarity, the lawyers in considering whether the CISG is an appropriate choice for the contract might be viewed against their client's best interest. In CISG member country, lawyers who automatically exclude CISG application risks their liability for malpractice and reproves by their professionality (Spagnolo, 2009b). The issue of unfamiliarity toward CISG is potentially the case if Indonesia ratified this convention, especially for legal practitioners. Apart from our education system in law school that provides a minimum amount of CISG learning, the judges will be the most difficult institution to undertake additional training for CISG.

\section{Indonesia's Stance in CISG}

Despite the facts CISG provides more advantages for the international contract, such as uniformity, legal certainty, and upholds monopolistic view with party autonomy at the outset; Indonesian government genuinely should ratify this convention. Since Indonesia happens to be a non-party of CISG, it resulted in Indonesian legal practitioners and academics' unfamiliarity with this convention. It can be found from a very minimum number of Indonesian scholars who write on this topic, especially in English. The last English journal addresses this issue was written by Surya Oktaviandra with the title "Indonesia and its reluctant to ratify the United Nations on Contract for the International Sales of Goods (CISG)" (Oktaviandra, 2018). In his paper, he described a primary reason why the Indonesian government still incline toward CISG, which relates to the Indonesian government's political will. Other urgent agenda is prioritized by the Indonesian government, especially concerning the national interest, such as enlarging national economy, promoting Indonesian socialculture, and improving legal institutions. The Indonesian government argued that the national economy is still recovering from the post-reformation period in Soeharto Regime dated back to 1998 when Indonesia has undergone a massive economic crisis. Economic policy has been created to improve trade expansion, with more than 154 regulations were revised since 2015 . The primary object for amending the economic policy and national law was to decrease the legal barrier, port and dwelling time, and logistics to establish a solid foundation for the futures traders. He also compared the study with the United Kingdom (UK), which has the same standpoint of not ratifying the CISG. The UK does not ratify the convention because the ministers of the country did not view the ratification of the convention as a legislative priority. The other country that delayed CISG ratification was Japan. The Japanese government was initially ready to ratify CISG in the 1990s. However, when the Asian Economic crisis 


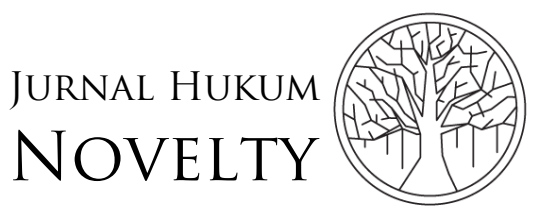

Volume 12, Issue 01, 2021, pp. 124-136

P-ISSN: $1412-6834$

E-ISSN: 2550-0090

hit Asia, it disturbed the initial plan and delayed its ratification until Japan rebuilt its economy in 2008 (Spagnolo, 2009b).

Indeed, Indonesia has been recovering from the economic crisis from the reformation period which occurred in the previous two decades. However, this does not give sufficient excuses for the government to neglect its function on improving international private law in Indonesia, which is ratifying this important convention. Asian economic crisis had happened in 1997, where Japanese banks were suffered from nonperforming loans due to devaluation of land price and currency depreciation, which experienced by most Asian banks. Despite the ability of most Asian countries to solve the problems, in November 1998, Japan initiated an assistance measure for Asian countries with approximately \$44 Billion and followed by South Korea and China (Ministry of Foregn Affairs of Japan, 2000). Furthermore, the Japanese government took extra measures in restructuring banks, such as creating new criteria to decrease nonperforming loans and restoring a robust financial sector (Ito, 1999). Even though the Japanese government was still recovering from the Asian economic crisis back in 2008, they chose to ratify the CISG. With the UK's view on CISG. The UK government thought the CISG is not urgent matters which is different from employment, civil partnerships, energy, and company law issues. Nevertheless, the UK has prominent laws on the contract, such as the Sales of Goods Act 1979 and the Supply of Goods and Services Act 1982. These laws contain contract regulation concisely, from contract formation (Sections 2 to 15B), effects of the contract (part III), contract performance (part IV), rights of the unpaid seller (part $\mathrm{V}$ ), actions for breach of contract (part VI), and its supplementary (part VII). The scope of these laws is not so distinct from CISG; it also covers international contracts and conflicts of law that might arise among the parties. Unlike Indonesian contract law, KUHPerdata is hardly comparable with the English Sales of Goods Act. Besides, two consultations have been made in the UK whether or not the UK should participate in CISG, which was in 1989 and 1997. Those consultations and meetings were held with the business community and academia to discuss UK participation in CISG. Still, it leads to the same result of not ratifying, and the UK business community viewed the law as "if it ain't broke, do not try to fix it" (Moss, 2005).

Afifah Kusumadara wrote the other major paper that talked about the important of CISG practice in Indonesia in her title "Pentingnya Ratifikasi UN Convention on Contract for the International Sales of Goods (CISG) oleh pemerintah Indonesia" (the importance of ratification of CISG by the Indonesian government) (Kusumadara, 2006). Her method was using field research by giving a questionnaire to business practices and law firms. The result of her research is $67 \%$ of Indonesian businesses do not classify the choice of law in their international sales contract as an important part of international trades activity, they have shown no objection if the contract was governed by encounter party law, which $75 \%$ of other parties were coming from CISG member countries such as Singapore, European Union, United States, Canada, Australia, and South Korea. Her questionnaire was subject to business actors, but she 
also referred to an Indonesian top law firm that mostly drafted the international sales contract. The result is similar to business actors, which governed the contract attributed to the encounter's party law (Kusumadara, 2006). Although this research was conducted more than ten years ago, it still indicates either business practices did not put the choice of law in their contract. It can be assumed that both business actors and Indonesian lawyers are not familiar with CISG. If 75\% of business partners are CISG members, when there is a dispute for this contract, and the choice of law falls under those country's law, CISG automatically applied (CISG, Art. 1(1)(a), direct application also knowns as automatic application).

Badan Pembinaan Hukum Nasional (BPHN) or Institution of National law, led by Hikmahanto Juwana issued an academic paper about ratification of CISG in 2013 (Juwana \& Tim Penyusun BPHN, 2013). His analysis covers the contents in CISG, KUHperdata, advantages, disadvantages of ratification, and ratification methods. Under chapter III, he analyzed the benefits of CISG ratification for Indonesia such as: (i) create a legal certainty for international commercial activities in Indonesia, particularly KUHPerdata does not provide solutions for complicated problems in international commercial law, (ii) ratification of CISG will create a better norm for source of national law and modernized the old colonization of Indonesian private law, (iii) CISG is part of international uniform law from different jurisdictions both common and civil law, it is flexible in nature, hence it will not disturb sharia law, (iv) create a positive effect for cross-border transactions in ASEAN and all counties, since transaction with CISG member states is increasing among business practices, and (v) Judging from the substances of CISG regarding the contract of sales and purchase of international goods, Indonesia's ratification to the CISG will create special source of legal principles for the sales and purchase of international goods. BPHN also noted several drawbacks for CISG ratification; (i) CISG only regulates sectoral transaction that is, the sales and purchase contract, it does not extend other international activities such as franchises, distributorship, commercial agency, countertrade, (ii) the fact that CISG derived from lex mercantoria, it does not provide a complete development national law of Indonesia. Moreover, in chapter IV about the analysis of CISG with KUHPerdata, CISG does not create any contradiction with the national contract at a quo. Instead, it will create more homework for the Indonesian government ratification is a starting point on how CISG will be enacted to national law. This academic manuscript seems to be forgotten by the Indonesian government; there was no follow-up after the publication of this paper in 2013 (Juwana \& Tim Penyusun BPHN, 2013).

\section{Recommendation for the Indonesian Government to Ratify CISG}

The ratification of CISG would bring enormous advantages for Indonesia, not only for the nation but also for the business community and legal practitioners. Indonesian civil code has been long-standing as the primary source for contract law in Indonesia; this Burgelijk Wetboek that has been applied in Indonesia was originally from the Napoleon Era before and was applied in Dutch commercial law (Soerodjo, 2016). In 


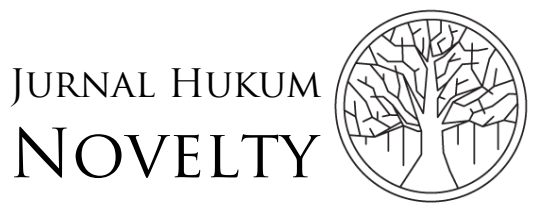

Volume 12, Issue 01, 2021, pp. 124-136

P-ISSN: $1412-6834$

E-ISSN: 2550-0090

the Netherlands, Indonesian-former colonizer has amended their Dutch Civil Code, particularly on contract law with the newest version under book 6 "the law of obligation" and book 7 "particular agreement." Whereas Indonesia is still stuck with book three, which is no longer relevant to the contract in the 21st century, including international contract sales. If the Indonesian government hopefully sooner to be a member of this convention, the ratification method can be in the form of law (undangundang) or through a presidential decree pursuant to article 10 Law No. 24 Year 2000 about International Treaty. Once Indonesia is part of CISG, if Indonesian businessman bounds in an international contract that is subject to Indonesian law and chooses not to exclude this convention's application, when there is a dispute on the contract, the CISG would automatically apply (Art. 1(1)(a) CISG). Thus, this would become extensive benefits to avoid conflict of law before the court because the judge would refer to CISG as the primary source of law. Moreover, with the elastic model of CISG, the business community always has the option of opt-in or opt-out the application of CISG. As stated in article 6, "the parties may exclude the application of this Convention or subject to article 12, derogate from or vary the effect of any of its provision". It means CISG upholds the freedom of contract principle and gives full power to the contractual party, and even more, it can harmonize the domestic law and international commercial law (De Ly, 2005).

When Indonesia ratifies this convention, the other essential point is it creates a new learning bargain for Indonesian legal practitioners to be familiar with the CISG application. As previously mentioned in Lisa Spagnolo's study, the reason most lawyers chose to opt-out CISG application is their unfamiliarity with the convention. If CISG is being imposed on Indonesian law, this unfamiliarity problem can be solved by introducing CISG in an educational institution in Indonesian universities. Legal practitioners such as lawyers, judges, and consultants obligate to learn the CISG and implement it in the workplace. This knowledge would create a strong bargaining position for Indonesia as a country since most of the encounter parties are from CISG member states, Indonesian law on international private law, and legal practitioners, leading to better legal institutions. For example, in China, nowadays Chinese are the dominant parties in international commerce. The country is known for pro-CISG jurisdiction whereby CISG is part of the curriculum in Chinese law school, and most Chinese lawyers chose to opt-in CISG that governs their client's international contract (Spagnolo, 2009b). Lastly, from the international political approach, the Indonesian government shall put the ratification of this convention into account, even North Korea is already a member of CISG since October 2018. Moreover, there has been an academic manuscript to encourage the Indonesian government to ratify this convention. It is time for Indonesia to step in and put the work into action for one and all.

\section{Conclusion}

With the rapid development of international sales and transactions, Indonesia is not yet ratifying CISG as part of the Indonesian source of law in terms of the international 
sales contract. While the existing contract law Burgelijk Wetboek considers being an ancient law from former Dutch colonialization since the 1880 s is seemingly no longer relevant to cover matters in international contract law. There were several reasons for the government of Indonesian to still reluctant on ratification, such as the Indonesian government still focus on recovering the economy after the Asian crisis that happened in the previous two decades and other agendas, especially in connection to the national interest in promoting Indonesian social-culture and strengthened legal institution. However, these reasons are no longer valid because the Indonesian economy thrives tremendously, particularly in a cross-border transaction where CISG member countries are involved. Furthermore, this convention's ratification will render more advantages for the country, not only for the source of law but also for legal certainty, solving the conflict of law problem, and improving knowledge of legal practitioners, which leads to improving Indonesia legal institutions. Ratification of CISG is essential because it will strengthen Indonesian international contract law by providing supplementary legal sources for existing law, such as KUHPerdata, since KUHPerdata accommodates minimum exposure to international contract law. Therefore, with plenty of advantages, the government can enact the law by creating undang-undang or just a presidential decree for ratification. As the author wrote in the title, if it is not now, then when?

\section{References}

Adiyanto, T. (2019). Dealing with unexpected circumstances: Judicial modification of contract under Indonesian and Dutch Law. Hasanuddin Law Review, 5(1), 102. https://doi.org/10.20956/halrev.v5i1.1508

Alper, G. (2021). CISG Advisory Council Opinions.

Case 54: CISG 1(1)(a);1(1)(b);4;79 Italy: Tribunale Civile di Monza between Nuova Fucinati S.p.A. v. Fondmetal International A.B. , (1993).

Checkley, J. C. (2020). The role of the CISG and international legal education: A model for future promotion of the CISG. Journal of Law and Commerce, 38(1). https://doi.org/10.5195/jlc.2020.202

Coyle, J. F. (2016). The role of the CISG in U.S. contract practice: An empirical study. University of Pennsylvania Journal of International Law, 38(1), 195-240.

De Ly, F. (2005). Sources of International sales Law: An Eclectic Model. Journal of Law and Commerce, 25(1), 1-12.

Economic Research and Statistics Division, \& The International Trade Statistics Section. (2019). World Trade Statistical Review 2019. In World Trade Organization.

Ewert, J.-P., \& Weslow, D. (2011). Fetatures: Forum Shopping in Europe and the United States. International Trademark Association Bulletin, 66(9).

Farnsworth, E. A. (1984). The Vienna Convention: History and Scope. Symposium/International Sale of Goods, 18(1).

Ferrante, E. (2019). Thirty years of CISG: International sales, 'Italian Style' CISG as a ratio scripta for international contracts and a model law for new legislation. The Italian Law Journal, 5(1). Retrieved from https://www.theitalianlawjournal.it/ferrante/?lang=it

Haeruddin, M.I.M, Mansur, M. A. R., Mansur, M., Thaief, I., \& Haeruddin, M. I. W. (2020). Keeping up with the CISG: A case of Indonesia. Iranian Economic Review, 24(4), 
923-933. https://doi.org/10.22059/ier.2020.78826

Ito, Takatoshi. (1999). Japan and the Asian Financial Crisis: The Role of Financial Supervision in Restoring Growth. In Institute of Economic Research Hitotsubashi University (Vol. 99).

Juwana, H., \& Tim Penyusun BPHN. Naskah Akademik tentang Ratifikasi Konvensi Mengenai Kontrak Jual Beli Barang Internasional. Badan Pembinaan Hukum Nasional Kementerian Hukum dan Hak Asasi Manusia § (2013).

Kusumadara, A. (2006). Pentingnya Ratifikasi UN Conventionnon Contracts for the International Sale of Goods (CISG) oleh Pemerintah Indonesia. Jurnal Forum Penelitian, (2).

Lookofsky, J. (2017). Understanding the CISG (Fifth (Wor). the Netherlands: Wolters Kluwer Law \& Business.

Maulana, H., Obst, P., \& Khawaja, N. (2018). Indonesian perspective of wellbeing: A qualitative study. Qualitative Report, 23(12), 3136-3152.

Matera, Joseph D. (2004). Comment: The United Nations Convention on Contracts for the International Sale of Goods ("CISG") and Geneva Pharmaceuticals Technology Corp. v. Barr Laboratories, Inc./Apothecon, Inc. v. Barr Laboratories, Inc.: The U.S. District Court for the Southern . 16 Pace International Law Review, pp. 165-174.

Ministry of Foreign Affairs of Japan. (2000). Asian Economic Crisis and Japan's Contribution.

Moss, S. (2005). Why the United Kingdom Has Not Ratified the CISG. Journal of Law and Commerce, 25, 483-485.

Murray, C., Holloway, D., \& Timson-Hunt, D. (2012). Schmitthoff the Law and Practice of International Trade. In Sweet \& Maxwell (12th ed.). London: Sweet \& Maxwell.

Ngoc, N. (2016). Business cooperation between Indonesia and Vietnam. Journal Sampurasun: Interdisciplinary Studies for Cultural Heritage, 2(1), 73. https://doi.org/10.23969/sampurasun.v2i01.112

Oktaviandra, S. (2018). Indonesia and Its Reluctance to Ratify the United Nations Convention on Contracts for the International Sale of Goods (CISG). Indonesia Law Review, 8(3), 243-255. https://doi.org/10.15742/ilrev.v8n3.340

Soerodjo, I. (2016). The development of Indonesian Civil Law. Scientific Research Journal (SCIRJ), 4(9), 30. Retrieved from http://www.scirj.org/sept-2016paper.php?rp=P0916357

Schill, Stephan. (2020). Yearbook Commercial Arbitration (Volume XLI). the Netherlands: Kluwer Law Inernational.

Spagnolo, L. (2009a). A Glimpse Through the Kaleidoscope: Choices of Law and the CISG (Kaleidoscope Part I). Vindobona Journal, 13, 135-156.

Spagnolo, L. (2009b). Rats in the Kaleidoscope: Rationality, Irrationality, and the Economics and Psychology of Opting In and Out of the CISG ( Kaleidoscope Part II ). Vindobona Journal, 13, 157-178.

Srivastava, A. (2020). Modern Law of International Trade: Comparative Export Trade and International Harmonization. In International Law and the Global South. https://doi.org/10.1007/978-981-15-5475-9

UNCITRAL. (2015). Thirty-five Years of Uniform Sales Law : Trends and Perspectives.

United Nations Commission on International Trade Law (UNCITRAL). (2020). United Nations Commission on International Trade Law 2020 CISG @ 40.

Worldometer. (2021). Indonesia Population (LIVE). 